Journal of Health Promotion and Behavior (2019), 4(1): 76-84

https://doi.org/10.26911/thejhpb.2019.04.01.08

\title{
The Contextual Effect of School on Smoking Behavior among Male High School Students
}

\author{
Tria Arifianti'), RB. Soemanto²), Hanung Prasetya ${ }^{3)}$ \\ 1)Masters Program in Public Health, Universitas Sebelas Maret \\ 2)Faculty of Social and Political Sciences, Universitas Sebelas Maret \\ 3)School of Health Polytechnics Surakarta
}

\begin{abstract}
Background: Indonesia was a country with high cigarette production and consumption. The smoking prevalence in adolescents aged 13-15 years in several countries included Argentina (3.7\%), Egypt (3.7\%), America (3.4\%) and Indonesia (2.8\%). The impact of cigarette exposure both as active and passive smokers such as the occurrence of various diseases included impotence, various types of cancer, respiratory diseases, coronary heart disease and others. This study aimed to analyze the contextual effect of school on smoking behavior among students.

Subjects and method: This was a cross sectional study conducted in Bantul, Yogyakarta, from April to May 2019. A sample of 200 male adolescents was selected by stratified random sampling. The dependent variable was smoking behavior. The independent variables were knowledge, family role, peer role, cigarette price, pocket money, and attitude. The data were collected by questionnaire. The data were analyzed by a multilevel multiple logistic regression run on Stata 13 .

Results: Smoking behavior was negatively associated with poor knowledge $(b=-3.30$; 95\% CI= 0.35 to $-0.09 ; \mathrm{p}=0.001)$, strong family role $(\mathrm{b}=-3.11 ; 95 \% \mathrm{CI}=-1.15$ to $-0.26 ; \mathrm{p}=0.002)$, strong peer role $(b=-3.92 ; 95 \% \mathrm{CI}=-1.10$ to $-0.36 ; \mathrm{p}<0.001)$, cigarette price $<\mathrm{Rp} 10,000(\mathrm{~b}=-2.81 ; 95 \%$ $\mathrm{CI}=-1.10$ to $-0.19 ; \mathrm{p}=0.005)$, money pocket $>\mathrm{Rp} 300,000(\mathrm{~b}=-3.79 ; 95 \% \mathrm{CI}=-5.75$ to -0.01 ; $\mathrm{p}<0.001)$, and negative attitude $(\mathrm{b}=-3.37 ; 95 \% \mathrm{CI}=-0.15$ to $-0.05 ; \mathrm{p}=0.001)$. School had contextual effect on smoking behavior with ICC $=14.00 \%$.

Conclusion: Smoking behavior is negatively associated with poor knowledge, strong family role, strong peer role, low cigarette price, high money pocket, and negative attitude. School has contextual effect on smoking behavior.
\end{abstract}

Keywords: smoking behavior, adolescents, peers, multilevel analysis

\section{Correspondence:}

Tria Arifianti. Masters Program in Public Health. Universitas Sebelas Maret. Jl. Ir. Sutami 36A, Surakarta 57126, Central Java. Email: tria.arifianti@gmail.com. Mobile: +6285866515112.

\section{BACKGROUND}

Indonesia is a country with high production and consumption of cigarettes. WHO data showed that Indonesia ranked number 3 after China and India as the countries which are most fond of smoking. At present, deaths from smoking have reached $50 \%$ in developing countries. In 2030 , it is estimated that the death rate from smoking in developing countries will reach 10 million, of which $70 \%$ are in developing countries (Ministry of Health, 2018).
Global Youth Tobacco Survey data in 2014 stated that Indonesia is the country with the highest number of teenage smokers in the world. $36.2 \%$ of adolescent boys and $4.3 \%$ of adolescents smoked. Nearly $80 \%$ of smokers started smoking when they had not reached 19 years. The age at first smoking was 12-15 years (42.3\%) (World Health Organization, 2015).

The number of smokers at the age of 10 years according to data taken from several provinces in Indonesia showed that 
Riau Islands ranks first with a prevalence value of $27.2 \%$ and Papua ranks as low as 16.2\% while DI Yogyakarta had a prevalence of $21.2 \%$ (Ministry of Health, 2018).

Data from the DIY Provincial Health Office in 2017 displayed that the percentage of population who smoked were those older that five years. Tobacco and smoking habits were recorded at $\mathbf{1 6 . 9 4 \%}$ every day and non-smoking every day was $2.46 \%$, while smoking behavior in urban districts in the Special Province of Yogyakarta was mostly in Gunung Kidul Regency, reaching 19.21\%, then in Kulon Progo Regency 17.78\%, Bantul Regency 16.52\%, Sleman Regency 16.32\% and in Yogyakarta City, 14.95\%. The health profile of Bantul Regency in 2018 reported that infectious diseases that are always included in the top ten diseases in public health center during the last few years were ARI and Hypertension. One of the causes of ARI was caused by the smoking behavior of people in the house.

Data from the Ministry of Health of the Republic of Indonesia stated that the number of smokers in one family in Indonesia was quite high. Reported that in one family, there were 1-2 people who smoked with the number of cigarettes smoked 1-2 packs / day. The results of the 2010 Riskesdas showed that $66.1 \%$ of smokers smoked at home with the percentage in Bantul of $80.5 \%$.

The high number of smokers in Indonesia really needs a strengthening as an effort to control the consumption of cigarettes. Efforts to control cigarette consumption were also conveyed by the Minister of Health of the Republic of Indonesia, Nila Farid Moeloek, at the 12th Asia Pacific Conference on Tobacco (APACT 12) on Health in Nusa Dua Bali, that all countries in the Asia Pacific were working together to control the impact of consumption disasters cigarettes. This problem became very important when various cases of non-communicable diseases caused by the chemical content of cigarettes were a big burden on the National Health Insurance (Ministry of Health, 2018).

BPJS Health data in 2016 also stated that the financing of health care for heart disease reaches 7.4 trillion rupiah, more than 10\% compared to the total BPJS contribution in 2016 of 67.4 trillion rupiah. Cardiovascular disease, such as heart disease and stroke, attacked 17.7 million people in the world, while the number of stroke in Indonesia reached $21.1 \%$, heart disease $12.9 \%$ and became the number one killer and one of the number two causes of all deaths in Indonesia (Ministry of Health, 2018).

Based on the description above, the authors were interested in conducting a study on "the contextual influence of schools on smoking behavior in students".

\section{SUBJECTS AND METHOD \\ 1. Study Design \\ A cross-sectional study was conducted at 25 senior high schools in Bantul, Yogyakarta, from April to May 2019.}

\section{Population and samples}

The study population was male adolescents in senior high schools in Bantul, Yogyakarta. A sample of 200 male students was selected by probability sampling.

\section{Study Variables}

The dependent variable was smoking behavior. The independent variables were knowledge, family role, peer role, cigarette prices, money pocket, attitude in level 1 and school in level 2.

\section{Operational Definition of Variables}

Knowledge. Knowledge was the result of learning from the subjects about the dangers of smoking. The measurement scale used in this study was a dichotomy. 
Journal of Health Promotion and Behavior (2019), 4(1): 76-84

https://doi.org/10.26911/thejhpb.2019.04.01.08

Family role. Family behavior was the attitude of adolescents to the behavior of parents who smoke. The measurement scale was dichotomous.

Peer role. Peers were those who had the same age and maturity at school. The measurement scale was dichotomous.

Price of cigarette. The price of cigarettes was a monetary unit or other measure (including goods or services) that was exchanged in order to obtain ownership rights or use of an item or service. The measurement scale was dichotomous.

Pocket Money. Pocket money was money given by parents to teenagers in the School. The measurement scale was dichotomous.

Attitude. Attitude was the perception of adolescents about smoking. The measurement scale was dichotomous.

Smoking behavior. Smoking behavior was the activity of smoking students. The measurement scale was dichotomous.

\section{Data Analysis}

Table 1. Univariate Analysis

\begin{tabular}{|c|c|c|}
\hline Independent Variable & $\mathbf{N}$ & $\%$ \\
\hline \multicolumn{3}{|l|}{ Smoking behavior } \\
\hline Not smoking & 140 & 70.0 \\
\hline Smoking & 60 & 30.0 \\
\hline \multicolumn{3}{|l|}{ Knowledge } \\
\hline Good & 136 & 68.0 \\
\hline Lacking & 64 & 32.0 \\
\hline \multicolumn{3}{|l|}{ Family Influence } \\
\hline No & 141 & 70.5 \\
\hline Yes & 59 & 29.5 \\
\hline \multicolumn{3}{|l|}{ Peer's Influence } \\
\hline No & 136 & 68.0 \\
\hline Yes & 64 & 32.0 \\
\hline \multicolumn{3}{|l|}{ Cigarette Price } \\
\hline Expensive $\geq \operatorname{Rp} 10,000$ & 148 & 74.0 \\
\hline Cheap >Rp 10,000 & 52 & 26.0 \\
\hline \multicolumn{3}{|l|}{ Pocket Money } \\
\hline$\leq \mathrm{Rp} 300,000$ & 149 & 74.5 \\
\hline$>\operatorname{Rp} 300,000$ & 51 & $25 \cdot 5$ \\
\hline \multicolumn{3}{|l|}{ Attitude } \\
\hline Positive & 141 & 70.5 \\
\hline Negative & 59 & 29.5 \\
\hline
\end{tabular}

Bivariate analysis was performed using chisquare test and calculation of odds ratio (OR) with a confidence level of 95\% CI to study the relationship between smoking behavior and independent variables. Multivariate analysis was performed using multilevel logistic regression.

\section{Research Ethics}

The research ethics included informed consent, anonymity, confidentiality, and research ethics. Research ethics was obtained from Dr. Moewardi Hospital, Surakarta, Central Java, with number: 501/IV/HERC/ 2019.

\section{RESULTS}

\section{Sample Characteristics}

The subjects in this study were 200 male adolescents. Characteristic frequency distribution and univariate analysis of smoking behavior in this study included knowledge, family influence, peers, cigarette price, pocket money, and attitude. 


\section{Univariate Analysis}

Table 1 showed that adolescents who smoked amounted to 30 subjects (30\%), lacking knowledge of 64 (32\%), family role amounting to 59 subjects (29.5\%), peer influence amounting to 64 subjects (32\%), cheap cigarette prices (26\%), pocket money $>\operatorname{Rp} 300,000$ amounting to 51 subjects (25.5\%), and negative attitude was 59 subjects (29.5\%).

\section{Bivariate Analysis}

Bivariate analysis was analyzed to examine the relationships of knowledge, family role, peer role, cigarette price, money pocket, attitude, and smoking behavior.

Table 2 showed that poor knowledge $(\mathrm{OR}=4.79 ; 95 \% \mathrm{CI}=2.50$ to $9.19, \mathrm{p}<0.001)$, family role $(\mathrm{OR}=6.01 ; 95 \% \mathrm{CI}=3.08$ to 11.74, $\mathrm{p}<0.001)$, peer role $(\mathrm{OR}=10.96 ; 95 \%$ $\mathrm{CI}=5.42$ to $22.19 ; \mathrm{p}<0.001)$, cigarette price $<\mathrm{Rp} 10,000(\mathrm{OR}=6.05 ; 95 \% \mathrm{CI}=3.04$ to 12.03; $\mathrm{p}<0.001)$, money pocket $>\mathrm{Rp}$ $300,000(\mathrm{OR}=6.41 ; 95 \% \mathrm{CI}=3.20$ to 12.82 ; $\mathrm{p}<0.001)$, and attitude $(\mathrm{OR}=12.73 ; 95 \%$ $\mathrm{CI}=6.18$ to $26.23 ; \mathrm{p}<0.001)$ increased smoking behavior.

Table 2. Bivariate analysis carried out was between smoking behavior with knowledge, family influence, peer influence, cigarette prices, pocket money, and attitude

\begin{tabular}{|c|c|c|c|c|c|c|c|c|}
\hline \multirow{3}{*}{ Independent Variable } & \multicolumn{4}{|c|}{ Smoking behavior } & \multirow{3}{*}{$\mathbf{O R}$} & \multicolumn{2}{|c|}{$95 \% \mathrm{CI}$} & \multirow{3}{*}{$\mathbf{p}$} \\
\hline & \multicolumn{2}{|c|}{ Yes } & \multicolumn{2}{|c|}{ No } & & \multirow{2}{*}{$\begin{array}{c}\text { Lower } \\
\text { Limit }\end{array}$} & \multirow{2}{*}{$\begin{array}{l}\text { Upper } \\
\text { Limit }\end{array}$} & \\
\hline & $\mathbf{n}$ & $\%$ & $\mathbf{n}$ & $\%$ & & & & \\
\hline Knowledge & & & & & 4.79 & 2.50 & 9.19 & $<0.001$ \\
\hline Lacking & 34 & 60 & 30 & 21.4 & & & & \\
\hline Good & 26 & 40 & 110 & 78.6 & & & & \\
\hline Family Influence & & & & & 6.01 & 3.08 & 11.74 & $<0.001$ \\
\hline Yes & 34 & 60 & 25 & 17.8 & & & & \\
\hline No & 26 & 40 & 115 & 82.2 & & & & \\
\hline Peer's Influence & & & & & 10.97 & 5.42 & 22.19 & $<0.001$ \\
\hline Yes & 41 & 64 & 23 & 16.4 & & & & \\
\hline No & 23 & 36 & 117 & 83.6 & & & & \\
\hline Cigarrete Price & & & & & 6.05 & 3.04 & 12.03 & $<0.001$ \\
\hline Cheap $\geq \operatorname{Rp} 10,000$ & 31 & 51.6 & 21 & 15.0 & & & & \\
\hline Expensive $<\mathrm{Rp} 10,000$ & 29 & 48.4 & 119 & 85.0 & & & & \\
\hline Pocket Money & & & & & 6.41 & 3.20 & 12.82 & $<0.001$ \\
\hline$>\operatorname{Rp} 300,000$ & 31 & 51.6 & 20 & 14.2 & & & & \\
\hline$\leq \mathrm{Rp} 300,000$ & 29 & 48.4 & 120 & 85.8 & & & & \\
\hline Attitude & & & & & 12.73 & 6.18 & 26.23 & $<0.001$ \\
\hline Negative & 40 & 66.6 & 19 & 13.5 & & & & \\
\hline Positive & 20 & 33.4 & 121 & 86.5 & & & & \\
\hline
\end{tabular}

\section{Multilevel Analysis}

Table 3 showed the results of multivariate analysis. Table 3 showed that poor knowledge $(\mathrm{b}=3.10 ; 95 \% \mathrm{CI}=0.83$ to $3.68 ; \mathrm{p}=$ o.002), strong family role $(b=3.20 ; 95 \%$ $\mathrm{CI}=0.75$ to $3.13 ; \mathrm{p}=0.001$ ), strong peer role $(b=4.05 ; 95 \% \mathrm{CI}=1.32$ to $3.82 ; \mathrm{p}=$ $0.001)$, cigarette price $<\mathrm{Rp} 10,000(\mathrm{~b}=$
$2.84 ; 95 \% \mathrm{CI}=0.57$ to $3.14 ; \mathrm{p}=0.005)$, money pocket $>\operatorname{Rp} 300,000(b=2.89 ; 95 \%$ $\mathrm{CI}=0.65$ to $3.43 ; \mathrm{p}=0.004)$, negative attitude $(\mathrm{b}=3.29,95 \% \mathrm{CI}=0.92$ to $3.59, \mathrm{p}$ $<0.001$ increased smoking behavior among male adolescents.

School had contextual effect on smoking behavior with ICC $=14.00 \%$. 
Table 3. Multiple logistic regression multilevel analysis results

\begin{tabular}{|c|c|c|c|c|}
\hline \multirow{2}{*}{ Independent Variable } & \multirow{2}{*}{ b } & \multicolumn{2}{|c|}{ CI 95\% } & \multirow[b]{2}{*}{$\mathbf{p}$} \\
\hline & & Lower Limit & Upper Limit & \\
\hline \multicolumn{5}{|l|}{ Fixed Effect } \\
\hline Knowledge (lacking) & 3.10 & 0.83 & 3.68 & 0.002 \\
\hline Family role (strong) & 3.20 & 0.75 & 3.13 & 0.001 \\
\hline Peer role (strong) & 4.05 & 1.32 & 3.82 & 0.001 \\
\hline Cigarette price $<\mathrm{Rp} 10.000$ & 2.84 & 0.57 & 3.14 & 0.005 \\
\hline Money pocket $>\operatorname{Rp} 300.000 /$ month & 2.89 & 0.65 & 3.43 & 0.004 \\
\hline Negative attitude & 3.29 & 0.92 & 3.59 & 0.001 \\
\hline \multicolumn{5}{|l|}{ Random Effect } \\
\hline \multicolumn{5}{|l|}{$\mathrm{N}$ observation $=200$} \\
\hline \multicolumn{5}{|l|}{$\mathrm{N}$ group $=25$} \\
\hline \multicolumn{5}{|l|}{ Average of group $=8, \min =8, \max =8$} \\
\hline \multicolumn{5}{|l|}{ Log likelihood $=-51.70 \mathrm{p}<0.001$} \\
\hline $\mathrm{ICC}=14.00 \%$ & & & & \\
\hline
\end{tabular}

\section{DISCUSSION \\ 1. The effect of knowledge on smoking behavior}

The results of this study showed that knowledge was positively associated with smoking behavior among male adolescents $(b=3.10 ; 95 \% \mathrm{CI}=0.83$ to $3.68 ; \mathrm{p}=0.002)$. Adolescents with a lack of knowledge increased smoking behavior by 3.10 units compared to adolescents with good knowledge.

Soesyasmoro et al. (2017) stated that knowledge about smoking was associated with smoking behavior and was statistically significant $(\mathrm{OR}=0.35 ; 95 \% \mathrm{CI}=0.13$ to 0.95; $\mathrm{p}=0.039)$. Someone with a good level of knowledge about smoking behavior including the content of the effects of smoking will prefer to stop smoking. This shows that appropriate knowledge for adolescents can encourage positive attitudes and promote healthy behavior (Park et al., 2018).

Lack of knowledge of teenagers about the content of smoking, the long-term effects of smoking can cause adolescents to take action to smoke (Kusma et al., 2010). To prevent smoking habits, it is important to introduce the dangers of smoking, cigarette content, dependence and ways to stop smoking in school (AlQahtani et al., 2017).

2. The effect of family role on smoking behavior

The results of this study indicated that parental role was associated with smoking behavior among male adolescents $(b=3.20$; $95 \% \mathrm{CI}=0.75$ to 3.13 ; $\mathrm{p}<0.001$ ). Adolescents who had high family support for smoking behavior increase smoking behavior by 3.20 units compared to adolescents with low family support for smoking behavior.

The results of this study were in line with the study of Pandayu et al. (2017) that families can influence smoking behavior. Families with parents who smoke influenced it because they are role models for their children. This influence can be caused where family support is the reason for teenagers who smoke (Panduwinata et al., 2019).

The family environment plays an important role in preventing or promoting smoking. Parents have a very important role in the process of developing children's behavior. Children will imitate good behavior from their parents (Alves et al., 2015). But if parents have bad behavior or habits such as father or mother smoking, the child 
will imitate the smoking habits of their parents (Roupa et al., 2016).

\section{The effect of peer role on smoking behavior}

The results of this study showed that peers had a significant influence on smoking behavior in adolescent boys $(b=4.05 ; 95 \%$ $\mathrm{CI}=1.32$ to $3.82 ; \mathrm{p}<0.001)$. Teenagers who had high peer support for smoking behavior increase smoking behavior by as much as 4.05 units compared with adolescents with low peer support for smoking behavior.

This is in line with the study of Joung et al. (2016) which shows that there is a positive peer influence on smoking behavior among adolescents. Teenagers who have smoker friends will be influenced by smoking behavior than teens who have peers who do not smoke. In adolescence individuals will spend more time with their peers (Soesyasmoro et al., 2017).

Peer groups have an important role in one's personal development in social life, besides that it allows adolescents to develop their identity. Peer groups are the second environment after the family. The perspective of a teenager about smoking behavior is strongly influenced by peers, because the perspective determines the decisions taken in the end whether a teenager will smoke or not. Most teens smoke when outside school. It is because smoking is not permitted in the school environment (Purnaningrum et al., 2017).

\section{The effect of cigarette price on smoking behavior}

The results of this study indicated the price of cigarettes had a significant influence on smoking behavior in adolescent boys $(b=$ 2.84; 95\% $\mathrm{CI}=0.57$ to $3.14 ; \mathrm{p}=0.005$ ). Adolescents with perceptions of low cigarette prices increased smoking behavior by 2.84 units compared to adolescents with the perception of expensive cigarette prices.
The results of this study are in line with the study of Yeh et al. (2017) which states that the price of cigarettes can affect smoking behavior. The increase in cigarette prices will reduce cigarette consumption. The increase in cigarette prices will make someone think again to buy cigarettes (Bader et al., 2011).

Some of the factors associated with smoking cessation behavior are the prices of cigarettes. Someone who thinks the price of expensive cigarettes will choose not to smoke compared to someone who thinks that the price of cigarettes is cheap. Higher cigarette prices seem to be associated with a greater advantage to stop smoking (Ross et al., 2011).

\section{The effect of pocket money on smoking behavior}

The results of this study indicated pocket money had a significant influence on smoking behavior in adolescent boys $(\mathrm{b}=$ 2.89; 95\% CI 0.65 to 3.43 ; $p=0.004$ ). Teenagers with pocket money $>$ Rp 300,000 increased smoking behavior by 2.89 units compared to teenagers with pocket money p Rp. 300,000.

The results of this study are in line with the study of Purnaningrum et al. (2017) which showed that there was a significant relationship between the availability of pocket money and smoking behavior. The high availability of pocket money would affect the increase in smoking behavior among adolescents compared to adolescents with sufficient pocket money.

There was a connection between smoking and pocket money. Pocket money was used by teenagers to buy something they want, including the desire of teenagers to buy or not a cigarette (Das et al., 2011).

\section{The effect of attitude on smoking behavior}

The results of this study indicated that attitude had a significant influence on 
smoking behavior $(\mathrm{b}=3.29$; 95\% $\mathrm{CI}=0.92$ to $3.59 ; \mathrm{p}<0.001)$. Teenagers who had a negative attitude increase smoking behavior by 3.29 units compared to teenagers who had a positive attitude.

This is in line with the study of Delpia et al. (2017) which states that attitudes have a positive influence through intention towards smoking behavior. Attitude leads to responses in the form of approval or support or not on an object, especially in this study, namely smoking prevention behavior. A positive or negative attitude can determine a person's behavior through his intentions, where the more positive a person's attitude is, the intention to do a behavior will be higher. High intention influences the person to conduct behavior, namely the behavior of preventing alcohol and smoking consumption (Panduwinata et al., 2019)

Atmojo et al. (201 7) states that there are several factors that relate to stopping smoking behavior, one of which is one's attitude towards smoking. Someone who has a negative attitude that supports smoking behavior supports teenagers to have the intention to keep smoking. Attitude is the strongest predictors of intention for smoking behavior in adolescents (Pandayu et al., 2017).

\section{The effect of school level on smoking behavior}

The results showed that there was a contextual influence at the school level on the variation of smoking behavior in adolescent boys $(\mathrm{ICC}=14.00 \%)$. Variations in smoking behavior in adolescent boys as much as $14.00 \%$ were influenced by schools. The ICC value in this study was greater than the benchmark $8-10 \%$ rule of thumb, so the contextual influences that in this study were schools were very important to note.

The results of the study by $\mathrm{Heo}$ et al. (2014) stated that there is an influence between schools and smoking behavior in adolescents. Schools that have no education about smoking tend to be more likely for teens who smoke money because of the lack of knowledge they have. Schools determine young people to have more opportunities to interact with people of the opposite gender, teenagers in this school can use cigarettes to project images of maturity. Teenagers tend to think that cigarettes are a symbol of maturity or attraction.

Based on the results of the study it can be concluded that there is a significant influence between knowledge, family influence, peers, cigarette prices, pocket money, and attitudes toward smoking behavior in adolescent boys. Variations at the school level indicate that there is a contextual influence on smoking behavior among male adolescent.

\section{AUTHOR'S CONTRIBUTION}

Tria Arifianti collected and processed the data. RB. Soemanto reviewed the manuscript. Hanung Prasetya examined the conceptual framework and research methodology.

\section{FUNDING AND SPONSORSHIP}

This study used the authors' independent fund.

CONFLICT OF INTEREST

There is no conflict of interest in this study.

ACKNOWLEDGEMENT

We would like to thank the high school / vocational school in the Bantul Regency area for helping with the study.

\section{REFERENCE}

$\overline{\text { AlQahtani J (2017). Knowledge, attitude }}$ and practice of tobacco smoking among health colleges students at 
Najran University, Saudi Arabia: a cross-sectional descriptive study. Journal of Health Specialties, 5(1):35. doi: 10.4103/2468-6360.198801.

Alves J, Federico B, Kinnunen, J, Perelman J, Richter M, Rimpela A, Robert, Kunst A, Lorant (2015). Smoking in school-aged adolescents: design of a social network survey in six European countries. Journal of Public Health, 8(2):239-342. https://doi.org/10.1093/-pubmed/fdwo40.

Atmojo JT, Soemanto RB, Murti B (2017). Determinants of successful smoking cessation in Surakarta, Central Java. Journal of Health Promotion and Behavior, 2(4):332-342. https://doi.org/10.26911/thejhpb.2017.02.04.05

Bader P, Boisclair D, Ferrence R (2011). Effects of tobacco taxation and pricing on smoking behavior in high risk populations: a knowledge synthesis. International Journal of Environmental Research and Public, 8(11):41184139. https://doi:10.3390/ijerph8114118.

Das S, Ghosh M, Sarkar M, Joardar S, Chatterjee R, Chatterjee S (2011). Adolescents speak: why do we smoke?. Journal of Tropical Pediatrics, 57(6):476480. doi: 10.1093/tropej/fmroo3.

Delpia YV, Murti B, Suryani N (2017). Theory of planned behavior: Analysis of factors affecting the preventive behaviors of alcohol consumption and smoking among students from West Kalimantan, in Yogyakarta. Journal of Health Promotion and Behavior, 1(2):62-69. doi: 10.26911/thejhpb.2016.01.02.01.

Heo J, Oh J, Subramanian S, Kawachi I (2014). Household and school-level influences on smoking behavior among Korean adolescents: A multilevel analysis. PLoS ONE, 9(6). doi: 10.1371/journal.pone.0098683.

Joung MJ, Han MA, Park J, Ryu SY (2016). Association between family and friend smoking status and adolescent smoking behavior and E-cigarette use in Korea, International Journal of Environmental Research and Public Health, 13(12):1183. doi: 10.3390/ijerph13121183.

Ministry of Health (2018). Main Results of Basic Health Research, Ministry of Health. Retrived from http://www.depkes.go.id/resources/download/infoterkini/materi_rakorpop_2018/Hasil\%20Riskesdas\%202018.pdf.

Kusma B, Quarcoo D, Vitzthum K, Welte T, MacHe S, Meyer-Falcke A, Groneberg DA, Raupach T (2010). Berlin's medical students' smoking habits, knowledge about smoking and attitudes toward smoking cessation counseling. Journal of Occupational Medicine and Toxicology, 5(9). doi: 10.1186/17456673-5-9.

Pandayu A, Murti B, Pawito (2017). Effect of Personal factors, family support, pocket money, and peer group, on smoking behavior in adolescents in Surakarta, Central Java. Journal of Health Promotion and Behavior, 2(2): 98-111. doi: 10.26911/thejhpb.2017.02.02.01.

Panduwinata AW, Murti B, Pawito (2019). Multilevel analysis of the effect of school and peer group on smoking behavior in adolescents in Banjarnegara. Journal of Health Promotion and Behavior, 3(3):166-178. doi: 10.26911/thejhpb.2018.03.03.04.

Park J, Lim MK, Lim S (2018). Influences of tobacco-related knowledge on awareness and behavior towards smoking. Journal of Korean Medical Science, 33(47):302. doi: 10.3346/jkms.- 
2018.33.e302.

Purnaningrum W D, Joebagio, Murti B (2017). Association between cigarette advertisement, peer group, parental education, family income, and pocket money with smoking behavior among adolescents in Karanganyar District, Central Java. Journal of Health Promotion and Behavior, 2(2):148-158. doi: 10.26911/thejhpb.2017.02.02.05.

Ross H, Blecher E, Yan L, Hyland A (2011). Do cigarette prices motivate smokers to quit?. New evidence from the ITC survey, 106(3):609-619. doi: 10.1111/j.1360-0443.2010.03192.x.

Roupa Z, Vasilopoulos A, Hatzoglou C, Gourgoulianis K, Kefaliakos A, Mechili EA, Archangelidi O, Mentzakis E, Diomidous M (2016). The effect of family and social environment on smoking behaviour in adolescence. European Scientific Journal, 12(2):62. doi: 10.19044/esj.2016.v12n2p62.

Soesyamoro R A, Demartoto A, Adriani RB (2017). Effect of knowledge, peer group, family, cigarette price, stipend, access to cigarette, and attitude, on smoking behavior. Journal of Health Promotion and Behavior, 1(3):201210. doi: 10.26911/thejhpb.2016.01.03.07 .

World Health Organization (2015) Global Youth Tobacco Survey (GYTS): Indonesia report. New Delhi: WHOSEARO. ISBN: 978-92-9022-487-7.

Yeh CY, Schafferer C, Lee JM, Ho LM, Hsieh CJ (2017). The effects of a rise in cigarette price on cigarette consumption, tobacco taxation revenues, and of smoking-related deaths in 28 EU countries - Applying threshold regression modelling. BMC Public Health, 17(1):676. doi: 10.1186/s12889-017-4685-x. 